\title{
KRITERIA KESESUAIAN LAHAN UNTUK BERBAGAI KOMODITAS DI TAMBAK
}

\author{
Akhmad Mustafa \\ Balai Penelitian dan Pengembangan Budidaya Air Payau \\ Jl. Makmur Dg. Sitakka No. 129, Maros 90512, Sulawesi Selatan \\ E-mail: akhmadmustafa@yahoo.com
}

\begin{abstract}
ABSTRAK
Budidaya tambak merupakan industri akuakultur terbesar di Indonesia yang sangat diharapkan menjadi andalan dalam mewujudkan visi: Indonesia penghasil produk kelautan dan perikanan terbesar 2015, serta misi: menyejahterakan masyarakat kelautan dan perikanan. Untuk mewujudkan visi dan misi tersebut, maka Kementerian Kelautan dan Perikanan telah mencanangkan program minapolitan dan industrialisasi kelautan dan perikanan. Komoditas yang menjadi andalan program minapolitan dan industrialisasi perikanan budidaya tambak adalah udang windu, udang vaname, ikan bandeng, dan ikan nila. Karena komoditas tersebut merupakan komo ditas yang berbasis lahan, sehingga untuk dapat hidup, tumbuh, dan berproduksi membutuhkan persyaratan tertentu yang berbeda satu samalainnya. Persyaratan tumbuh atau persyaratan penggunaan lahan yang diperlukan oleh masingmasing komoditas dapat dijadikan dasar dalam menyusun kriteria kesesuaian lahan. Pada evaluasi lahan yang didasarkan pada sumberdaya fisik, empat faktor/sub-model telah dipertimbangkan sebagai kriteria kesesuaian lahan untuk budidaya tambak yaitu: topografi dan hidrologi, kondisi tanah, kualitas air, dan iklim dengan masing-masing nilai kriteria peubah yang berbeda-beda pada kelas kesesuaian dan komoditas yang berbeda pula.
\end{abstract}

\section{KATA KUNCl: udang, ikan, kriteria, kesesuaian lahan, tambak}

\section{PENDAHULUAN}

Perikanan budidaya (akuakultur) yang sekarang ini dilaksanakan di Indonesia secara umum meliputi: budidaya laut, budidaya air payau, dan budidaya air tawar. Budidaya air payau atau budidaya tambak di Indonesia telah lama dilakukan yaitu sejak abad ke-14 dengan budidaya ikan bandeng (Chanos chanos) di tambak di Pulau
Jawa (Ismail et al., 1994). Khusus untuk budidaya udang windu (Penaeus monodon) di tambak, dimulai pada tahun 1964 di Kabupaten Jeneponto, Sulawesi Selatan setelah daerah penangkapan benur (benih urang) windu diketemukan di Kabupaten Bulukumba, Jeneponto, dan Pinrang (Poernomo, 1979). Perkembangan budidaya udang windu di tambak tergolong sangat pesat, sehingga pada tahun 1986 berkembanglah budidaya udang windu secara semi-intensif dan intensif yang dimulai di Pulau Jawa (Poernomo, 1988). Sebagai akibat serangan penyakit terutama penyakit bercak putih atau White Spot Syndrome Virus (WSSV) terhadap udang windu sejak tahun 1997, menyebabkan banyak dari tambak tersebut menjadi telantar atau dengan produksi yang sangat rendah. Sebagai akibat kegagalan dalam produksi udang windu, akhirnya pemerintah secara resmi melepas udang vaname (Litopenaeus vannamei) sebagai varietas unggul pada 12 Juli 2001 melalui SK Menteri Kelautan dan Perikanan No. 41/2001. Ikan nila (Oreochromis niloticus) adalah salah satu ikan air tawar yang sejak diintroduksi pada tahun 1969 (Soewito et al., 2011) telah mengalami perkembangan di berbagai aspek yang cukup cepat termasuk budidayanya di tambak.

Kementerian Kelautan dan Perikanan (KKP) telah memfokuskan untuk meningkatkan produksi perikanan budidaya dan mengendalikan perikanan tangkap. Oleh karena itu, peluang sekaligus tumpuan besar akan tertuju pada akuakultur. Potensi tambak di Indonesia seluas 1.224.076 ha, akan tetapi yang telah dimanfaatkan seluas 612.530 ha. Budidaya tambak merupakan industri akuakultur terbesar di Indonesia yang sangat diharapkan menjadi andalan dalam mewujudkan visi: Indonesia penghasil produk kelautan dan perikanan terbesar 2015, serta misi: menyejahterakan masyarakat kelautan dan perikanan. Untuk mewujudkan visi dan misi tersebut, maka KKP telah mencanangkan program minapolitan dan industrialisasi perikanan budidaya tambak dengan komoditas andalan untuk budidaya tambak antara lain udang windu, udang vaname, ikan bandeng, dan ikan nila. Komoditas tersebut adalah komoditas berbasis lahan yang untuk tumbuh, hidup, dan berproduksi memerlukan 
persyaratan lahan yang dapat berbeda satu dengan lainnya.

Secara umum, tambak dijumpai di kawasan pesisir yang masih dipengaruhi oleh pasang surut. Namun demikian, tidak semua lahan di kawasan pesisir sesuai untuk tambak. Oleh karena itu, evaluasi lahan perlu dilakukan untuk menjadi dasar pertimbangan dalam pengambilan keputusan penggunaan lahan. Menurut Rossiter (1996), evaluasi lahan sangat penting dilakukan karena lahan memiliki sifat fisik, sosial, ekonomi, dan geografi yang bervariasi atau dengan kata lain lahan diciptakan tidak sama. Adanya variasi sifat tersebut dapat mempengaruhi penggunaan lahan termasuk untuk budidaya tambak. Oleh karena itu, tujuan penulisan makalah ini adalah memberikan informasi mengenai kriteria kesesuaian lahan untuk berbagai komoditas budidaya tambak yang didahului dengan penjelasan singkat tentang evaluasi lahan maupun struktur klasifikasi kesesuaian lahan untuk budidaya tambak.

\section{Evaluasi Lahan}

Dalam kaitannya dengan sumberdaya alam, dikenal istilah lahan (land) dan tanah (soil) yang pengertiannya seringkali rancu. Sesungguhnya pengertian lahan lebih luas daripada tanah sebagaimana dalam pengertian berikut ini. Sumberdaya lahan merupakan suatu lingkungan fisik yang terdiri atas tanah, topografi, hidrologi, vegetasi, dan iklim di mana pada batas-batas tertentu mempengaruhi kemampuan penggunaan lahan (FAO, 1976). Dengan demikian dalam pengertian lahan, tanah termasuk di dalamnya.

Dalam memanfaatkan sumberdaya lahan untuk penggunaan lahan tertentu, diperlukan pertimbangan yang matang dalam mengambil keputusan mengingat tingginya persaingan dalam penggunaan lahan, baik untuk kepentingan produksi pertanian termasuk perikanan maupun untuk keperluan non pertanian seperti pemukiman dan industri. Oleh karena itu, lahan perlu diklasifikasikan berdasarkan kelas kemampuan atau kelas kesesuaiannya untuk penggunaan tertentu.

Evaluasi lahan merupakan suatu proses pendugaan keragaan Iahan apabila lahan digunakan untuk tujuan tertentu (FAO, 1985) atau sebagai metode yang menjelaskan atau memprediksi kegunaan potensial dari lahan (van Diepen et al., 1991). Apabila potensi lahan sudah dapat ditentukan, maka perencanaan penggunaan lahan dapat dilakukan berdasarkan pertimbangan yang rasional, paling tidak mengenai apa yang dapat ditawarkan oleh sumberdaya lahan tersebut (FAO, 1995). Dengan demikian, evaluasi lahan merupakan alat perencanaan penggunaan lahan yang strategis. Evaluasi lahan memprediksi keragaan lahan mengenai keuntungan yang diharapkan dari penggunaan lahan dan kendala penggunaan lahan yang produktif serta degradasi lingkungan yang diperkirakan akan terjadi karena penggunaan lahan.

Berdasarkan pada tujuan evaluasi lahan, klasifikasi lahan dapat berupa klasifikasi kemampuan lahan atau klasifikasi kesesuaian lahan. Klasifikasi kesesuaian lahan bersifat spesifik untuk suatu komoditas tertentu. Klasifikasi kemampuan lahan adalah penilaian komponenkomponen lahan secara sistematik dan pengelompokannya ke dalam beberapa kategori berdasarkan atas sifat-sifat yang merupakan potensi dan penghambat dalam penggunaannya secara berlanjut (FAO, 1976). Klasifikasi kemampuan lahan merupakan klasifikasi potensi lahan untuk penggunaan berbagai sistem pertanian secara umum tanpa menjelaskan peruntukan jenis komoditas tertentu maupun tindakan-tindakan pengelolaannya.

\section{Struktur Klasifikasi Kesesuaian Lahan}

Pedoman evaluasi lahan yang banyak digunakan dalam penelitian maupun dalam proyek evaluasi lahan adalah Kerangka Kerja Evaluasi Lahan FAO (FAO, 1976). Khusus untuk budidaya tambak, Hardjowigeno et al. (1996) telah mengembangkan kesesuaian lahan untuk tambak (Land Suitability for Brackish Water Fishponds) yang juga mengacu pada evaluasi lahan FAO (1976). Namun demikian, kriteriakriteria kesesuaian lahan yang dikemukakan masih sangat terbatas. Klasifikasi kesesuaian lahan menyangkut perbandingan antara kualitas lahan dengan persyaratan penggunaan lahan yang diinginkan. Struktur klasifikasi kesesuaian lahan, menurut kerangka kerja FAO (1976), terdiri atas empat kategori dan struktur ini jugalah yang digunakan dalam makalah ini, yaitu:

- Ordo (Order): Menunjukkan keadaan kesesuaian secara umum

- Kelas (Class) : Menunjukkan tingkat kesesuaian dalam ordo

- Sub-kelas (Sub-class) : M enunjukkan keadaan tingkatan dalam kelas yang didasarkan pada faktor pembatas (constrain) atau macam perbaikan yang diperlukan dalam kelas

- Satuan (Unit) : M enunjukkan tingkatan dalam sub-kelas yang didasarkan pada perbedaan-perbedaan kecil yang berpengaruh dalam pengelolaannya.

Ordo kesesuaian lahan menurut Kerangka Kerja Evaluasi Lahan FAO (FAO, 1976) dibedakan atas:

- Ordo S: Sesuai (Suitable). Lahan yang termasuk dalam ordo ini dapat digunakan untuk penggunaan tertentu 
secara berlanjut, tanpa atau sedikit risiko kerusakan terhadap sumberdaya lahannya. Dengan kata lain, keuntungan lebih besar dari masukan yang diberikan.

- Ordo N : Tidak sesuai (Not suitable). Lahan yang termasuk dalam ordo ini mempunyai faktor pembatas sedemikian rupa sehingga mencegah penggunaan secara berlanjut untuk suatu tujuan yang direncanakan.

Kelas kesesuaian lahan merupakan pembagian lebih lanjut dari ordo dan menggambarkan tingkat kesesuaian dari suatu ordo. Tingkat dalam kelas ditunjukkan oleh angka (nomor urut) yang ditulis di belakang simbol. Nomor urut tersebut menunjukkan tingkatan kelas yang menurun dalam suatu ordo. Pada dasarnya jumlah kelas dalam tiap ordo tidak terbatas, tetapi dianjurkan untuk memakai tiga kelas dalam Ordo $\mathrm{S}$ dan dua kelas dalam Ordo N.

Pembagian dan definisi secara kualitatif masing-masing kelas jika menggunakan tiga kelas untuk Ordo $\mathrm{S}$ dan dua kelas untuk Ordo N, adalah sebagai berikut:

- Kelas S1 : Sangat sesuai (Highly Suitable)

Lahan tidak mempunyai faktor pembatas yang berat untuk penggunaan secara berkelanjutan atau hanya mempunyai faktor pembatas tidak berarti dan tidak berpengaruh nyata terhadap produksi serta tidak menyebabkan kenaikan masukan yang diberikan pada umumnya.

- Kelas S2 : Cukup sesuai (M oderately Suitable) Lahan mempunyai faktor pembatas agak berat untuk mempertahankan tingkat pengelolaan yang harus dilakukan. Faktor pembatas akan mengurangi produktivitas dan keuntungan, serta meningkatkan masukan yang diperlukan.

- Kelas S3 : Sesuai marjinal atau sesuai bersyarat (Marginally Suitable)

Lahan mempunyai faktor pembatas yang sangat berat untuk mempertahankan tingkat pengelolaan yang harus dilakukan. Faktor pembatas akan mengurangi produktivitas dan keuntungan. Perlu ditingkatkan masukan yang diperlukan.

- Kelas N1 : Tidak sesuai saat ini (Currently not Suitable) Lahan mempunyai faktor pembatas yang lebih berat, tetapi masih mungkin untuk diatasi, hanya tidak dapat diperbaiki dengan tingkat pengetahuan sekarang ini dengan biaya yang rasional. Faktor pembatasnya begitu berat sehingga menghalangi keberhasilan penggunaan lahan yang berkelanjutan dalam jangka panjang.

- Kelas N2 : Tidak sesuai selamanya (Permanently not Suitable)
Lahan mempunyai faktor pembatas yang sangat berat, sehingga tidak mungkin digunakan bagi suatu penggunaan yang berkelanjutan.

Sub-kelas kesesuaian lahan menunjukkan faktor pembatas atau macam perbaikan yang diperlukan dalam suatu kelas kesesuaian lahan. Kesesuaian pada tingkat unit merupakan pembagian lebih lanjut dari sub-kelas kesesuaian lahan yang didasarkan atas besarnya faktor pembatas. Dengan demikian, semua unit dari sub-kelas yang sama memiliki tingkat kesesuaian yang sama dalam kelas dan memiliki faktor pembatas yang sama pada tingkat sub-kelas.

\section{Kriteria Kesesuaian Lahan}

Evaluasi lahan merupakan proses penilaian potensi suatu lahan untuk penggunaan-penggunaan spesifik yang dilakukan dengan cara-cara tertentu, yang nantinya akan menjadi dasar pertimbangan dalam pengambilan keputusan penggunaan lahan seperti tambak (Mustafa et al., 2007a). Evaluasi lahan didasarkan pada analisis hubungan antara lahan dan penggunaan lahan, mengestimasi masukan yang dibutuhkan serta keluaran yang diinginkan.

Evaluasi lahan mencakup dua aspek pokok yaitu: a) sumberdaya fisik: tanah, air, topografi dan iklim, serta b) sumberdaya sosial ekonomi: ukuran lahan pembudidaya, tingkat pengelolaan, ketersediaan tenaga kerja, letak pasar, dan aktivitas manusia lainnya. Sumberdaya fisik dapat dianggap sebagai sifat yang relatif stabil, sedangkan sumberdaya sosial ekonomi lebih beragam dan tergantung pada keputusan sosial dan politik. Untuk budidaya tambak, kriteria yang akan digunakan dalam evaluasi lahan hanya dibatasi pada aspek sumberdaya fisik saja. Chanrantchakool et al. (1995) menyatakan aspek penting yang perlu dipertimbangkan dalam evaluasi lahan untuk budidaya tambak meliputi: sumber air, kualitas tanah, dan ketersediaan infrastruktur. Poernomo (1979) menyatakan bahwa aspek penting yang harus memenuhi persyaratan dalam evaluasi lahan untuk budidaya tambak adalah aspek ekologi dan topografi, tanah, dan biologi. Aspek rekayasa, kualitas tanah, kualitas air, dan fasilitas infrastruktur adalah aspek yang dipertimbangkan oleh Karthik et al. (2005) dalam evaluasi lahan untuk budidaya tambak.

Semua jenis komoditas termasuk perikanan yang berbasis lahan untuk dapat tumbuh, hidup, dan berproduksi memerlukan persyaratan-persyaratan tertentu yang dapat berbeda satu sama lain. Persyaratan tumbuh atau persyaratan penggunaan lahan yang diperlukan oleh masing-masing komoditas mempunyai batas kisaran minimal, optimal, dan maksimal (Mustafa 
et al., 2007b; 2008). Untuk menentukan kelas kesesuaian lahan, persyaratan tersebut dijadikan dasar dalam menyusun kriteria kelas kesesuaian lahan, yang dikaitkan dengan karakteristik lahan. Karakteristik lahan yang optimal bagi kebutuhan komoditas atau penggunaan lahan tersebut merupakan batasan bagi kelas kesesuaian yang sangat sesuai (kelas S1). Kualitas lahan yang di bawah optimal merupakan batasan kelas kesesuaian lahan antara kelas yang cukup sesuai (kelas S2), dan atau sesuai marjinal (kelas S3). Di luar batasan tersebut merupakan lahan-lahan yang secara fisik tergolong tidak sesuai (kelas N). Faktor/ sub-model dan peubah yang dijadikan sebagai kriteria kesesuaian lahan untuk berbagai komoditas di tambak dijelaskan pada bagian berikut:

\section{Topografi dan Hidrologi}

Topografi berupa bentuk wilayah atau kemiringan lereng dapat mempengaruhi kemampuan suatu lahan dalam pengisian maupun pergantian air tambak, terutama tambak yang dikelola secara tradisional (ekstensif) dan madya (semi-intensif). Secara umum, lahan di kawasan pesisir tergolong datar, walaupun pada daerah-daerah tertentu tergolong landai atau berombak. Chanractchakool et al. (1995) menyarankan lahan yang baik untuk budidaya tambak adalah relatif datar. Walaupun kawasan pertambakan relatif datar, tetapi ketinggian tempatnya atau elevasinya di atas tinggi permukaan air pasang tertinggi juga dapat menyebabkan lahan sulit untuk diisi air secara gravitasi. Sebaliknya, ketinggian tempat di bawah permukaan air surut terendah juga menyebabkan kesulitan dalam pengeringan maupun pembuangan air tambak. Dengan demikian, elevasi tambak yang baik adalah elevasi di mana penggalian diminimalkan namun dapat diperoleh kedalaman air tambak yang dikehendaki. Selain itu, biaya konstruksi tambak dapat diminimalkan juga, sedangkan kesuburan tanah dasar dapat dipertahankan. Menurut Bose et al. (1991), bahwa elevasi dasar tambak yang ideal adalah apabila dasar tambak dapat dikeringkan kapan saja dan dapat diisi air secara gravitasi selama 5 hari dari setiap siklus pasang surut.

Dibandingkan dengan tambak budidaya ikan bandeng dan ikan nila, tambak budidaya udang terutama udang vaname memerlukan air lebih dalam. Kisaran pasang surut yang ideal untuk tambak adalah antara 1,5 $\mathrm{m}$ dan 2,5 m. Daerah pantai dengan kisaran pasang surut kurang dari 1,0 m sangat sulit untuk pengisian maupun pengeluaran air tambak secara gravitasi. Sebaliknya daerah pantai yang kisaran pasang surutnya lebih dari 2,5 m juga terlalu berat untuk budidaya tambak, sebab pematang terpaksa dibuat besar dan tinggi agar mampu menahan tekanan air waktu pasang tinggi dan surut rendah.

\section{Kondisi Tanah}

Perubahan sifat-sifat tanah tergantung dari waktu seperti disajikan pada Tabel 1. Pelapukan kimia dan fisik sekalipun dalam kondisi ideal memerlukan ratusan atau bahkan ribuan tahun untuk berkembang menjadi tanah dewasa yang matang. Oleh karena itu, dalam pemilihan kriteria kualitas tanah untuk budidaya tambak, dipilih peubah yang besar pengaruhnya terhadap budidaya tambak, tetapi peubah tersebut bersifat stabil atau agak sulit berubah.

Dalam konstruksi tambak harus dilakukan penggalian agar tambak yang dikonstruksi mampu menahan air, maka kedalaman tanah yang dapat digali menjadi bahan pertimbangan. Yang dimaksudkan dengan kedalaman tanah adalah ketebalan tanah tambak dari permukaan tanah sampai lapisan yang padas keras. Untuk tambak budidaya udang vaname, maka tambak sebaiknya digali minimal sampai 2,0 m; sebab kedalaman air tambak yang baik untuk budidaya udang vaname antara 1,5 m-1,8 m. Untuk tambak budidaya udang windu, kedalaman air yang dibutuhkan yaitu antara 1,0 m-1,2 m, sedangkan kedalaman air yang lebih dangkal yaitu antara 0,5 m-1,0 m adalah untuk budidaya ikan bandeng dan ikan nila.

Tabel 1. Sifat-sifat tanah yang berubah dengan waktu

\begin{tabular}{lll}
\hline & Sifat-sifat yang berubah dalam hitungan & \\
\hline Menit atau jam & \multicolumn{1}{c}{ Bulan atau tahunan } & Ratusan atau ribuan tahun \\
\hline Suhu & $\mathrm{pH}$ & Jenis mineral \\
Kelembaban & Warna & Sebaran ukuran butir \\
Komposisi udara dalam pori-pori tanah & Struktur & Pembentukan horison \\
& Kandungan bahan organik & \\
& Kesuburan tanah & \\
& Kepadatan mikroorganisme & \\
\hline
\end{tabular}

Sumber: Anonymous (2001) 
Pirit $\left(\mathrm{FeS}_{2}\right)$ adalah senyawa yang kandungannya tergolong tinggi pada tanah sulfat masam. Dalam kondisi alami yaitu dalam keadaan tereduksi, keberadaan pirit tidak menimbulkan masalah dalam budidaya tambak. Akan tetapi, bila pirit tersebut terekspos udara karena digali untuk tambak maka akan menyebabkan terjadinya oksidasi pirit yang menyebabkan penurunan $\mathrm{pH}$ tanah secara drastis dan peningkatan kelarutan unsur toksik yang drastis pula dan sebagai akibat lanjut adalah rendahnya produktivitas tambak. Oleh karena itu, lapisan pirit sebaiknya dihindari dalam pemilihan lokasi untuk budidaya tambak.

Tekstur tanah merupakan perbandingan antara fraksi liat, debu, dan pasir dari tanah. Tekstur tanah tambak sangat berpengaruh terhadap porositas dan pertumbuhan klekap yang dapat menjadi salah satu sumber makanan bagi ikan dan udang. Tambak dengan tanah bertekstur kasar seperti pasir dan pasir berlempung memiliki tingkat porositas yang tinggi, sebagai akibatnya tambak tidak bisa menahan air. Tanah tambak sering dijumpai bertekstur halus dengan kandungan liat minimal 20\%30\% untuk menahan peresapan ke samping (Boyd, 1995). Tekstur tanah yang baik untuk tambak adalah: liat, lempung berliat, lempung liat berdebu, lempung berdebu, lempung, dan lempung liat berpasir (Ilyas et al., 1987).

$\mathrm{pH}_{\mathrm{F}}$ adalah $\mathrm{pH}$ tanah yang diukur langsung di lapangan, sedangkan $\mathrm{pH}_{\mathrm{Fox}}$ adalah $\mathrm{pH}$ tanah yang diukur di lapangan setelah dioksidasi dengan hidrogen peroksida $30 \%$ keduanya merupakan peubah yang khas pada tanah sulfat masam. Selisih nilai $\mathrm{pH}_{\mathrm{F}}$ dan $\mathrm{pH}_{\mathrm{FOX}}\left(\mathrm{pH}_{\mathrm{F}}-\mathrm{pH}_{\mathrm{FOX}}\right)$ dapat digunakan sebagai indikator besarnya nilai potensi kemasaman pada tanah sulfat masam. Dalam hal ini, semakin besar nilai $\mathrm{pH}_{\mathrm{F}}-\mathrm{pH}_{\mathrm{Fox}}$ menunjukkan semakin besar potensi kemasaman pada tanah sulfat masam.

Kebanyakan tanah adalah tanah mineral, tetapi tanah tersebut mangandung bahan organik. Bahan organik di tambak dapat berpengaruh terhadap kestabilan tanah, konsumsi oksigen, sumber unsur hara, dan kesesuaian habitat dari dasar tambak. Pada permukaan tanah $(0 \mathrm{~m}$ $0,2 \mathrm{~m}$ ) dari tanah mineral yang digunakan untuk pertanian jarang mengandung $5 \% 6 \%$ bahan organik dan di daerah tropik dan subtropik kandungan bahan organik biasanya lebih rendah (Boyd, 1995). Pada tanah yang mengandung liat yang tinggi (>60\%), Boyd (1995) menetapkan kandungan bahan organik < 8\%tergolong slight yaitu baik dan faktor pembatasnya mudah diatasi untuk budidaya tambak. Namun demikian, kandungan bahan organik yang sangat tinggi dapat menurunkan kualitas lingkungan budidaya tambak. Proses dekomposisinya yang menghasilkan senyawa-senyawa yang bersifat racun juga merupakan dampak negatif dari bahan organik ini.

\section{Kualitas Air}

Karena komoditas yang dibudidayakan di tambak hidup dalam badan air, maka kualitas air merupakan faktor penentu keberhasilan budidaya di tambak. Kualitas air yang baik untuk budidaya di tambak jika air dapat mendukung kehidupan organisme akuatik dan jasad makanannya pada setiap stadium pemeliharaan. Peubah kualitas air yang penting untuk budidaya di tambak adalah kecerahan, suhu, salinitas, $\mathrm{pH}$, dan $\mathrm{NH}_{3}$.

Kecerahan air tambak ditentukan oleh derajat kekeruhan air yang disebabkan oleh kandungan suspensi partikel organik, koloid tanah atau kepadatan plankton. Khusus pada tambak baru yang dibangun pada tanah gambut atau tanah sulfat masam, kecerahan dapat berkurang karena adanya suspensi partikel atau senyawa hidroksida besi $\left(\mathrm{Fe}(\mathrm{OH})_{3}\right.$ ) atau karena asam-asam organik dan zat tanin yang larut dari sisa-sisa akar tumbuhan dan menyebabkan air berwarna coklat kehitaman (Poernomo, 1988). Dikatakan pula bahwa, batas kecerahan yang layak untuk udang windu adalah $0,25 \mathrm{~m}-0,60 \mathrm{~m}$ dan optimalnya 0,30 m-0,40 m. Menurut Stickney (2000), ikan nila mempunyai toleransi yang tinggi terhadap kekeruhan.

Sebagai negara tropis, Indonesia tidak menghadapi fluktuasi suhu musiman yang besar. Fluktuasi suhu yang dapat menimbulkan masalah adalah fluktuasi suhu harian. Perbedaan suhu antara siang dan malam hari cukup besar yaitu $10^{\circ} \mathrm{C}$ terutama pada tambak-tambak dangkal. Suhu air yang layak untuk budidaya udang windu berkisar antara $26^{\circ} \mathrm{C}$ dan $32^{\circ} \mathrm{C}$ dan optimalnya antara $29^{\circ} \mathrm{C}$ dan $30^{\circ} \mathrm{C}$ (Poernomo, 1988). Suhu optimal untuk pertumbuhan udang vaname adalah $28^{\circ} \mathrm{C}-30^{\circ} \mathrm{C}$ (Ponce-Palatox et al., 1997). Suhu air yang baik untuk ikan bandeng adalah $27^{\circ} \mathrm{C}$ $31^{\circ} \mathrm{C}$ (Ismail et al., 1993). Suhu air optimal bagi budidaya ikan nila adalah $25^{\circ} \mathrm{C}-30^{\circ} \mathrm{C}$ (Stickney, 2000; Hossain et al., 2007) dan dapat mentolerir suhu antara $15^{\circ} \mathrm{C}$ dan $37^{\circ} \mathrm{C}$ (Wiryanta et al., 2010).

Salinitas adalah jumlah total material padat dalam garam yang terkandung dalam satu kilogram air laut bila karbonat telah dikonversi menjadi oksida, bromida, dan iodida diganti dengan klorida dan bahan organik telah dioksidasi secara sempurna (Boyd, 1995). Pengaruh langsung salinitas terhadap organisme akuatik adalah melalui efeknya terhadap kandungan dan tekanan osmotik cairan dalam tubuh organisme akuatik (Poxton, 2003). Pada perairan pesisir, nilai salinitas sangat dipengaruhi oleh masukan air tawar dari sungai. Udang windu, udang 
vaname, ikan bandeng, dan ikan nila merupakan organisme eurihalin, namun karena dibudidayakan untuk tujuan komersial, kisaran salinitas yang optimal perlu dipertahankan. Udang windu mampu menyesuaikan diri terhadap salinitas air 3-45 ppt, namun untuk pertumbuhan optimal diperlukan salinitas air 15-25 ppt (Poernomo, 1988). Udang vaname umumnya tumbuh optimal pada salinitas air 15-20 ppt (Bray et al., 1994). Ikan bandeng dapat tumbuh optimal pada salinitas air 15-30 ppt (Ismail et al., 1993). Ikan nila dapat hidup pada kisaran salinitas yang cukup lebar, sehingga ikan ini dapat dibudidayakan pada dua ekosistem yang berbeda yaitu air tawar dan air payau (Watanabe, 2000; Hossain et al., 2007).

Batas toleransi organisme akuatik terhadap $\mathrm{pH}$ bervariasi dan dipengaruhi oleh banyak faktor, antara lain: suhu oksigen terlarut, alkalinitas, dan adanya anion dan kation, serta jenis dan stadium organisme. Kisaran $\mathrm{pH}$ yang baik untuk udang windu adalah 7,5-8,7 dengan optimal 8,0-8,5 (Poernomo, 1988). Ikan bandeng tumbuh dengan optimal pada pH air 7,0-8,5 (Ismail et al., 1993). Menurut Swingle (1968), pada umumnya pH air yang baik bagi organisme akuatik adalah 6,5-9,0; pada pH 9,5-11,0 dan 4,0-6,0 mengakibatkan produksi rendah dan jika lebih rendah dari 4,0 atau lebih tinggi 11,0 akan meracuni ikan.

Amonia dapat berada dalam bentuk molekul $\left(\mathrm{NH}_{3}\right)$ atau bentuk ion $\mathrm{NH}_{4}$, di mana $\mathrm{NH}_{3}$ lebih beracun daripada $\mathrm{NH}_{4}$ (Poernomo, 1988). $\mathrm{NH}_{3}$ dapat menembus bagian membran sel lebih cepat daripada $\mathrm{NH}_{4}$. Kandungan $\mathrm{NH}_{3}$ 0,05-0,20 mg/L sudah menghambat pertumbuhan organisme akuatik pada umumnya. Apabila kandungan $\mathrm{NH}_{3}$ lebih dari 0,2 mg/L; perairan bersifat toksik bagi beberapa jenis ikan (Sawyer \& McCarty, 1978). Chanratchakool et al. (1995) menyatakan bahwa kandungan amonia yang diperkenankan untuk budidaya udang windu adalah kurang dari 0,1 mg/L. Menurut Stickney (2000), ikan nila termasuk jenis ikan yang tahan terhadap kandungan amonia yang tinggi. Ikan tidak dapat bertoleransi terhadap kandungan $\mathrm{NH}_{3}$ yang terlalu tinggi, karena dapat mengganggu proses pengikatan oksigen oleh darah dan pada akhirnya dapat mengakibatkan sufokasi.

\section{Iklim}

Kondisi rata-rata cuaca pada periode yang panjang dikenal dengan iklim. Unsur-unsur iklim yang penting untuk budidaya tambak adalah curah hujan. Curah hujan antara 2.000-3.000 mm/tahun dengan bulan kering 2-3 bulan cukup baik untuk tambak (Mustafa et al., 2011). Bulan kering menurut klasifikasi iklim dari Schmidt \& Ferguson (1951) adalah bulan dengan curah hujan $<60$ mm. Persiapan tambak adalah salah satu kegiatan yang harus dilakukan sebelum dilakukan penebaran. Pada saat persiapan tambak dilakukan pengeringan tambak dengan tujuan untuk memperbaiki sifat fisik tanah, meningkatkan mineralisasi bahan organik dan menghilangkan bahanbahan beracun berupa hidrogen sulfida, amonia, dan metan. Karena itu, diperlukan adanya bulan-bulan kering tertentu pada setiap tahun.

Kriteria kesesuaian lahan untuk budidaya udang windu, udang vaname, ikan bandeng, dan ikan nila berturut-turut dapat dilihat pada Tabel 2, 3, 4, dan 5. Asumsi yang diterapkan dalam kriteria kesesuaian lahan untuk budidaya tambak adalah disesuaikan pada pengelolaan yang rendah atau sederhana. Khusus kriteria kesesuaian lahan untuk ikan nila, maka tidak dipertimbangkan untuk ikan nila Srikandi yang memiliki toleransi salinitas antara 0 sampai 40 ppt dengan optimal antara10 sampai dengan 30 ppt seperti tercantum dalam Keputusan Menteri Kelautan dan Perikanan Republik Indonesia Nomor KEP.09/MEN/2012 Tentang Pelepasan Ikan Nila Srikandi. Kriteria yang dibuat ini dapat digunakan untuk pemetaan tingkat detail (skala 1:10.000) dan pemetaan tingkat semi-detail (skala 1:50.000 dan 1:25.000).

Di kawasan pesisir, di mana tersedia sumberdaya lahan untuk budidaya tambak, dijumpai berbagai kawasan yang tergolong Kawasan Lindung. Pada Pasal 1 Keputusan Presiden Nomor 32 Tahun 1990 (Keppres 32 1990) Tentang Pengelolaan Kawasan Lindung dijelaskan bahwa Kawasan Lindung adalah kawasan yang ditetapkan dengan fungsi utama melindungi kelestarian lingkungan hidup yang mencakup sumberdaya alam, sumberdaya buatan dan nilai sejarah dan budaya bangsa guna kepentingan pembangunan berkelanjutan. Dua Kawasan Lindung yang sangat penting diperhatikan dalam kesesuaian lahan untuk budidaya tambak adalah Sempadan Sungai dan Kawasan Pantai Berhutan Bakau. Pada Pasal 16 Keppres 321990 telah ditetapkan bahwa kriteria Sempadan Sungai adalah sekurang-kurangnya 100 m di kiri kanan sungai besar dan $50 \mathrm{~m}$ di kiri kanan anak sungai yang berada di luar pemukiman. Pada Pasal 27 Keppres 321990 telah ditetapkan bahwa kriteria Kawasan Pantai Berhutan Bakau adalah minimal 130 kali nilai rata-rata perbedaan air pasang tertinggi dan terendah tahunan diukur dari garis air surut terendah ke arah darat. Di dalam Kawasan Lindung dilarang melakukan kegiatan budidaya kecuali yang tidak mengganggu fungsi lindung seperti tertera pada Pasal 37 Keppres 32 1990. Oleh karena itu, kawasan pertambakan yang termasuk dalam Kawasan Lindung disarankan untuk dianggap sebagai faktor pembatas yang tidak dianalisis dalam kesesuaian lahan untuk budidaya tambak. 
Tabel 2. Kriteria kesesuaian lahan untuk budidaya udang windu (Penaeus monodon) di tambak

\begin{tabular}{|c|c|c|c|c|}
\hline \multirow{2}{*}{ Faktor dan Peubah } & \multicolumn{4}{|c|}{ Kelas } \\
\hline & S1 & $\mathbf{S 2}$ & S3 & $\mathbf{N}$ \\
\hline \multicolumn{5}{|l|}{ Topografi dan hidrologi } \\
\hline - Kelerengan $(\%$ & $<0,1$ & $0,1-1,0$ & $1,0-2,0$ & $>2,0$ \\
\hline - Pasang surut (m) & $1,5-2,5$ & $1,0-1,5 ; 2,5-3,0$ & $0,5-1,0 ; 3,0-3,5$ & $<0,5 ;>3,5$ \\
\hline \multicolumn{5}{|l|}{ Kondisi tanah } \\
\hline - Ketebalan tanah sampai mencapai batuan (m) & $>2,0$ & $1,5-2,0$ & $1,0-1,5$ & $<1,0$ \\
\hline - Kedal aman pirit (m) & $>2,0$ & $1,0-2,0$ & $0,5-1,0$ & $<0,5$ \\
\hline - Liat $(\%)$ & $10-20$ & $20-30$ & $30-60$ & $<10 ;>60$ \\
\hline - $\mathrm{pH}_{\mathrm{F}-\mathrm{pH}} \mathrm{pOX}$ & $<0,5$ & $0,5-1,5$ & $1,5-4,0$ & $>4,0$ \\
\hline - Karbon-organik (\%) & $1,5-2,5$ & $0,5-1,5$ & $<0,5 ; 2,5-8,0$ & $>8,0$ \\
\hline \multicolumn{5}{|l|}{ Kualitas air } \\
\hline - Kecerahan (m) & $0,30-0,40$ & $0,25-0,30 ; 0,40-0,50$ & $0,20-0,25 ; 0,50-0,60$ & $<0,20 ;>0,60$ \\
\hline - Suhu $\left({ }^{\circ} \mathrm{C}\right)$ & $28-30$ & $20-28 ; 30-35$ & $12-20 ; 35-40$ & $<12 ;>40$ \\
\hline - Salinitas (ppt) & $15-25$ & $10-15 ; 25-32$ & $5-10 ; 32-40$ & $<5 ;>40$ \\
\hline$-\mathrm{pH}$ & $7,5-8,5$ & $6,0-7,5 ; 8,5-9,5$ & $4,0-6,0 ; 9,5-11,0$ & $<4,0 ;>11,0$ \\
\hline - Amonia (mg/L) & $<0,1$ & $0,1-0,2$ & $0,2-0,3$ & $>0,3$ \\
\hline \multicolumn{5}{|l|}{ Iklim } \\
\hline - Curah hujan tahunan (mm/tahun) & $2.500-3.000$ & $2.000-2.500$ & $1.000-2.000 ; 3.000-3.500$ & $<1.000 ;>3.500$ \\
\hline - Bulan kering & $1-2$ & $2-3$ & $3-5$ & $<1 ;>5$ \\
\hline
\end{tabular}

Tabel 3. Kriteriakesesuaian lahan untuk budidaya udang vaname (Litopenaeus vannamei) di tambak

\begin{tabular}{|c|c|c|c|c|}
\hline \multirow{2}{*}{ Faktor dan Peubah } & \multicolumn{4}{|c|}{ Kelas } \\
\hline & S1 & S2 & S3 & $\mathbf{N}$ \\
\hline \multicolumn{5}{|l|}{ Topografi dan hidrologi } \\
\hline - Kelerengan $(\%$ & $<0,1$ & $0,1-1,0$ & $1,0-2,0$ & $>2,0$ \\
\hline - Pasang surut (m) & $1,5-2,5$ & $1,0-1,5 ; 2,5-3,0$ & $0,5-1,0 ; 3,0-3,5$ & $<0,5 ;>3,5$ \\
\hline \multicolumn{5}{|l|}{ Kondisi tanah } \\
\hline - Ketebalan tanah sampai mencapai batuan (m) & $>2,5$ & $1,5-2,5$ & $1,0-1,5$ & $<1,0$ \\
\hline - Kedalaman pirit (m) & $>2,5$ & $1,5-2,5$ & $0,5-1,5$ & $<0,5$ \\
\hline - Liat $(\%$ & $10-20$ & $20-30$ & $30-60$ & $<10 ;>60$ \\
\hline$-\mathrm{pH}_{\mathrm{F}}-\mathrm{pH} \mathrm{H}_{\mathrm{FOX}}$ & $<0,5$ & $0,5-1,5$ & $1,5-4,0$ & $>4,0$ \\
\hline - Karbon-organik (\%) & $1,5-2,5$ & $0,5-1,5$ & $<0,5 ; 2,5-8,0$ & $>8,0$ \\
\hline \multicolumn{5}{|l|}{ Kualitas air } \\
\hline - Kecerahan (m) & $0,30-0,40$ & $0,25-0,30 ; 0,40-0,50$ & $0,20-0,25 ; 0,50-0,60$ & $<0,20 ;>0,60$ \\
\hline - Suhu $\left({ }^{\circ} \mathrm{C}\right)$ & $28-30$ & $20-28 ; 30-35$ & $12-20 ; 35-40$ & $<12 ;>40$ \\
\hline - Salinitas (ppt) & $15-20$ & $10-15 ; 20-30$ & $<10 ; 30-50$ & $>50$ \\
\hline$-\mathrm{pH}$ & $7,5-8,5$ & $6,0-7,5 ; 8,5-9,5$ & $4,0-6,0 ; 9,5-11,0$ & $<4,0 ;>11,0$ \\
\hline - Amonia (mg/L) & $<0,1$ & $0,1-0,2$ & $0,2-0,3$ & $>0,3$ \\
\hline \multicolumn{5}{|l|}{ Iklim } \\
\hline - Curah hujan tahunan (mm/tahun) & $2.500-3.000$ & $2.000-2.500$ & $1.000-2.000 ; 3.000-3.500$ & $<1.000 ;>3.500$ \\
\hline - Bulan kering & $1-2$ & $2-3$ & $3-5$ & $<1 ;>5$ \\
\hline
\end{tabular}


Tabel 4. Kriteria kesesuaian lahan untuk budidaya ikan bandeng (Chanos chanos) di tambak

\begin{tabular}{|c|c|c|c|c|}
\hline \multirow{2}{*}{ Faktor dan Peubah } & \multicolumn{4}{|c|}{ Kelas } \\
\hline & S1 & $\mathbf{S 2}$ & S3 & $\mathbf{N}$ \\
\hline \multicolumn{5}{|l|}{ Topografi dan hidrologi } \\
\hline - Kelerengan $(\%)$ & $<0,1$ & $0,1-1,0$ & $1,0-2,0$ & $>2,0$ \\
\hline - Pasang surut (m) & $1,5-2,5$ & $1,0-1,5 ; 2,5-3,0$ & $0,5-1,0 ; 3,0-3,5$ & $<0,5 ;>3,5$ \\
\hline \multicolumn{5}{|l|}{ Kondisi tanah } \\
\hline - Ketebalan tanah sampai mencapai batuan (m) & $>2,0$ & $1,5-2,0$ & $1,0-1,5$ & $<1,0$ \\
\hline - Kedalaman pirit (m) & $>2,0$ & $1,0-2,0$ & $0,5-1,0$ & $<0,5$ \\
\hline - Liat $(\%$ & $10-20$ & $20-30$ & $30-60$ & $<10 ;>60$ \\
\hline$-\mathrm{pH}_{\mathrm{F}-\mathrm{pH}} \mathrm{FOX}$ & $<1,0$ & $1,0-3,0$ & $3,0-5,0$ & $>5,0$ \\
\hline - Karbon-organik (\%) & $1,5-2,5$ & $0,5-1,5$ & $<0,5 ; 2,5-8,0$ & $>8,0$ \\
\hline \multicolumn{5}{|l|}{ Kualitas air } \\
\hline - Kecerahan (m) & $0,30-0,40$ & $0,25-0,30 ; 0,40-0,50$ & $0,20-0,25 ; 0,50-0,60$ & $<0,20 ;>0,60$ \\
\hline - Suhu $\left({ }^{\circ} \mathrm{C}\right)$ & $28-30$ & $20-28 ; 30-35$ & $12-20 ; 35-40$ & $<12 ;>40$ \\
\hline - Salinitas (ppt) & $15-20$ & $10-15 ; 20-30$ & $<10 ; 30-50$ & $>50$ \\
\hline$-\mathrm{pH}$ & $7,5-8,5$ & $6,0-7,5 ; 8,5-9,5$ & $4,0-6,0 ; 9,5-11,0$ & $<4,0 ;>11,0$ \\
\hline - Amonia (mg/L) & $<0,1$ & $0,1-0,2$ & $0,2-0,3$ & $>0,3$ \\
\hline \multicolumn{5}{|l|}{ Iklim } \\
\hline - Curah hujan tahunan (mm/tahun) & $2.500-3.000$ & $2.000-2.500$ & $1.000-2.000 ; 3.000-3.500$ & $<1.000 ;>3.500$ \\
\hline - Bulan kering & $1-2$ & $2-3$ & $3-5$ & $<1 ;>5$ \\
\hline
\end{tabular}

Tabel 5. Kriteria kesesuaian lahan untuk budidaya ikan nila (Oreochromis niloticus) di tambak

\begin{tabular}{|c|c|c|c|c|}
\hline \multirow{2}{*}{ Faktor dan Peubah } & \multicolumn{4}{|c|}{ Kelas } \\
\hline & S1 & S2 & S3 & $\mathbf{N}$ \\
\hline \multicolumn{5}{|l|}{ Topografi dan hidrologi } \\
\hline - Kelerengan $(\%$ & $<0,1$ & $0,1-1,0$ & $1,0-2,0$ & $>2,0$ \\
\hline - Pasang surut (m) & $1,5-2,5$ & $1,0-1,5 ; 2,5-3,0$ & $0,5-1,0 ; 3,0-3,5$ & $<0,5 ;>3,5$ \\
\hline \multicolumn{5}{|l|}{ Kondisi tanah } \\
\hline - Ketebalan tanah sampai mencapai batuan (m) & $>2,0$ & $1,5-2,0$ & $1,0-1,5$ & $<1,0$ \\
\hline - Kedalaman pirit (m) & $>2,0$ & $1,0-2,0$ & $0,5-1,0$ & $<0,5$ \\
\hline - Liat $(\%)$ & $10-20$ & $20-30$ & $30-60$ & $<10 ;>60$ \\
\hline$-\mathrm{pH}_{\mathrm{F}}-\mathrm{pH}_{\mathrm{FOX}}$ & $<1,5$ & $1,5-3,5$ & $3,5-6,0$ & $>6,0$ \\
\hline - Karbon-organik (\%) & $1,5-2,5$ & $0,5-1,5$ & $<0,5 ; 2,5-8,0$ & $>8,0$ \\
\hline \multicolumn{5}{|l|}{ Kualitas air } \\
\hline - Kecerahan (m) & $0,30-0,40$ & $0,20-0,30$ & $0,10-0,20$ & $<0,10 ;>0,40$ \\
\hline$-\operatorname{Suhu}\left({ }^{\circ} \mathrm{C}\right)$ & $28-30$ & $20-28 ; 30-35$ & $12-20 ; 35-40$ & $<12 ;>40$ \\
\hline - Salinitas (ppt) & $<10$ & $10-25$ & $25-35$ & $>35$ \\
\hline$-\mathrm{pH}$ & $7,5-8,5$ & $6,0-7,5 ; 8,5-9,5$ & $4,0-6,0 ; 9,5-11,0$ & $<4,0 ;>11,0$ \\
\hline - Amonia (mg/L) & $<0,3$ & $0,3-0,4$ & $0,4-0,5$ & $>0,5$ \\
\hline \multicolumn{5}{|l|}{ Iklim } \\
\hline - Curah hujan tahunan (mm/tahun) & $2.500-3.000$ & $2.000-2.500$ & $1.000-2.000 ; 3.000-3.500$ & $<1.000 ;>3.500$ \\
\hline - Bulan kering & $1-2$ & $2-3$ & $3-5$ & $<1 ;>5$ \\
\hline
\end{tabular}


Klasifikasi kesesuaian lahan dilakukan dengan menyusun matriks kesesuaian lahan atas dasar pemberian nilai pada setiap peubah pembatas budidaya tambak. Metode ini dikenal dengan metode pemberian nilai atau pengharkatan (scoring). M etode lain yang dapat digunakan adalah metode pencocokan (matching). Pada metode pemberian nilai, kelas sangat sesuai (kelas S1) diberi nilai 4, kelas cukup sesuai (kelas S2) diberi nilai 3, kelas kurang sesuai (kelas S3) diberi nilai 2, dan kelas tidak sesuai (kelas N) diberi nilai 1. Pada penentuan kesesuaian lahan dengan metode pemberian nilai, maka pembobotan (weighting) setiap faktor/sub-model atau peubah sangat menentukan hasil kesesuaian lahan. Meskipun terdapat beberapa teknik untuk pembobotan (Malczewski, 1999), pada Gambar 1 diperlihatkan hasil pembobotan dari setiap faktor/sub-model atau peubah dari kriteria yang menggunakan proses hirarki analitik atau PHA (analytic hierarchy process atau AHP) yang dikenal dengan perbandingan berpasangan (pairwise comparison) (Saaty, 1977; 1993; Malczewski, 1999). Pada metode ini, pendapat ahli dan studi pustaka serta pengalaman empirik yang telah dilakukan dapat menjadi dasar dalam pembobotan. Keunggulan menggunakan PHA adalah dapat mengukur rasio konsistensi (consistency ratio) dengan melihat indeks konsistensi (consistency index) dari distribusi bobot yang diperoleh (Radiarta et al., 2011). Indeks ini menggambarkan konsekuensi dari proses pembobotan, dan menunjukkan probabilitas nilai yang ditentukan secara acak. Nilai rasio konsistensi sama dengan 0,02 diperoleh pada pembobotan kriteria kesesuaian lahan untuk budidaya tambak (Gambar 1). Nilai rasio konsistensi 7 0,10 merupakan nilai yang dapat diterima dan menunjukkan pembobotan yang konsisten (Saaty, 1977; Banai-Kashani, 1989; Alonso \& Lamata, 2006) dan artinya metode PHA menghasilkan solusi optimal.

\section{PENUTUP}

Komoditas yang menjadi andalan program minapolitan dan industrialisasi perikanan budidaya tambak adalah udang windu, udang vaname, ikan bandeng, dan ikan nila. Karena komoditas tersebut merupakan komoditas yang berbasis lahan, sehingga membutuhkan persyaratan tertentu yang berbeda satu sama lainnya untuk dapat hidup, tumbuh dan berproduksi. Persyaratan tumbuh atau persyaratan penggunaan lahan yang diperlukan oleh masing-masing komoditas dapat dijadikan dasar dalam

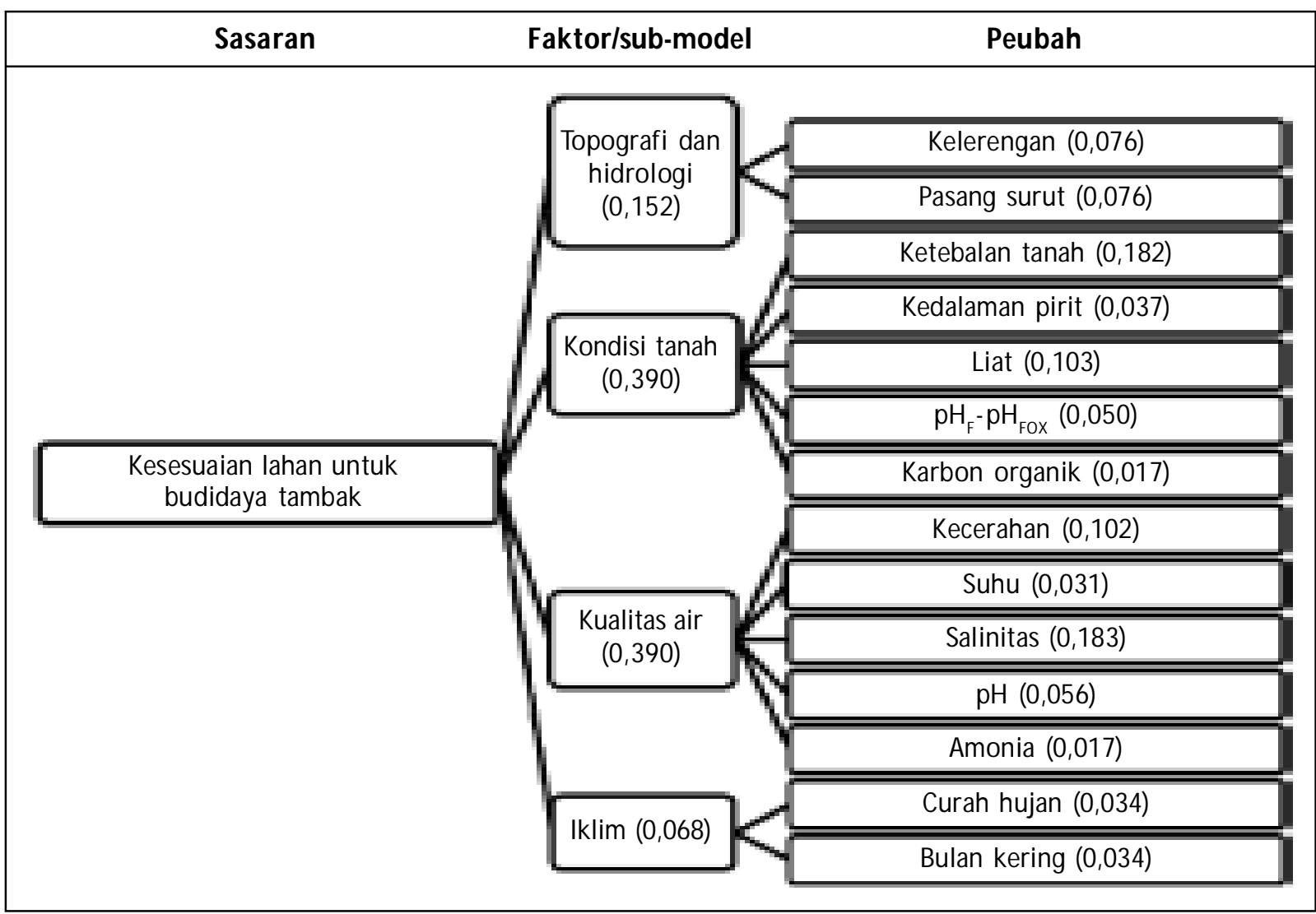

Gambar 1. Model hirarki kesesuaian lahan untuk budidaya tambak (angka menunjukkan bobot untuk setiap faktor/sub-model dan peubah) 
menyusun kriteria kesesuaian lahan. Pada evaluasi lahan yang didasarkan pada sumberdaya fisik, empat faktor/submodel telah dipertimbangkan sebagai kriteria kesesuaian lahan untuk budidaya tambak yaitu: topografi dan hidrologi, kondisi tanah, kualitas air, dan iklim dengan masing-masing nilai kriteria yang berbeda-beda pada kelas kesesuaian dan komoditas yang berbeda pula. Kriteria kesesuaian lahan untuk budidaya tambak ini dapat digunakan dalam pemetaan tingkat detail dan semidetail.

\section{DAFTAR ACUAN}

Alonso, J.A. \& Lamata, M.T. 2006. Consistency in the analytic hierarchy process: a new approach. International Journal of Uncertainty, Fuzziness and KnowledgeBased Systems, 14(4): 445-459.

Anonymous. 2001. Soil Morphogenesis. Agro/Hort 100 Intro to Plant Science Soils. Cited in http:// weather.nsmu.edu/Teaching M aterial/so il350/ Soil\%20M orphogenesis.htm. [1 Juli 2003].

Banai-Kashani, R. 1989. A new method for site suitability analysis: the analytic hierarchy process. Environmental Management, 13: 685-693.

Bose, A.N., Ghosh, S.N., Yang, C.T., \& Mitra, A. 1991. Coastal Aquaculture Engineering. Chapman and Hall, Inc., New York, 365 pp.

Boyd, C.E. 1995. Bottom Soils, Sediment, and Pond Aquaculture. Chapman and Hall, New York, 348 pp.

Bray, W.A., Lawrence, A.L., \& Leung-Trujillo, J.R. 1994. The effect of salinity on growth and survival of Penaeus vannamei, with observations on the interaction of IHHN virus and salinity. Aquaculture, 122: 133-146.

Chanratchakool, P., Turnbull, J.F., Funge-Smith, S., \& Limsuwan, C. 1995. Health Management in Shrimp Ponds. Second edition. Aquatic Animal Health Research Institute, Department of Fisheries, Kasetsart University Campus, Bangkok, 111 pp.

Dieven, van C.A., Keulen, van H., Wolf, J., \& Berkhout, J.A.A. 1991. Land evaluation: from intuition to quantification. In Stewart, B.A. (Ed.), Advances in Soil Science. Springer, New York, p. 139-204.

Food and Agriculture Organization (FAO). 1976. A framework for land evaluation. In FAO Soil Bulletin 32. Soil Resources Management and Conservation Service and Water Development Division, FAO, Rome, 72 pp.

Food and Agriculture Organization (FAO). 1985. Guidelines: land evaluation for irrigated agriculture. In FAO Soil Bulletin 55. Soil Resources Management and Conservation Service and Water Development Division, FAO, Rome, 231 pp.
Food and Agriculture Organization (FAO). 1995. Planning for sustainable use of land resources: towards a new approach. In FAO Land and Water Bulletin 2. FAO, Rome, $60 \mathrm{pp}$.

Hardjowigeno, S., Soekardi, M., Djaenuddin, D., Suharta, N., \& Jordens, E.R. 1996. Kesesuaian Lahan untuk Tambak. Pusat Penelitian Tanah dan Agroklimat, Bogor, $17 \mathrm{hlm}$.

Hossain, M.S., Chowdhury, S.R., Das, N.G., \& Rahaman, M.M. 2007. Multi-criteria evaluation approach to GISbased land-suitability classification for tilapia farming in Bangladesh. Aquaculture International, 15(6): 425443.

Ilyas, S., Cholik, F., Poernomo, A., Ismail, W., Arifudin, R., Daulay, T., Ismail, A., Koesoemadinata, S., Rabegnatar, I N.S., Soepriyadi, H., Suharto, H.H., Azwar, Z.I., \& Ekowardoyo, S. 1987. Petunjuk Teknis bagi Pengoperasian Unit Usaha Pembesaran Udang Windu. Pusat Penelitian dan Pengembangan Perikanan, Jakarta, $100 \mathrm{hlm}$.

Ismail, A., Poernomo, A., Sunyoto, P., Wedjatmiko, Dharmadi, \& Budiman, R.A.I. 1993. Pedoman Teknis Usaha Pembesaran Ikan Bandeng di Indonesia. Pusat Penelitian dan Pengembangan Perikanan, Jakarta, 73 hlm.

Karthik, M., Suri, J., Saharan, N., \& Biradar, R.S. 2005. Brackish water aquaculture site selection in Palghar Taluk, Thane district of Maharashtra, India, using the techniques of remote sensing and geographical information system. Aquacultural Engineering, 32: 285302.

Malczewski, J. 1999. GIS and Multicriteria Decision Analysis. John Wiley \& Sons, New York, 392 pp.

Mustafa, A., Paena, M., Tarunamulia, \& Sammut, J. 2008. Hubungan antara faktor kondisi lingkungan dan produktivitas tambak untuk penajaman kriteria kesesuaian lahan. 2. Kualitas tanah. J. Ris. Akuakultur, 3(1): 105-121.

Mustafa, A., Rachmansyah, \& Hanafi, A. 2007a. Kelayakan lahan untuk budi daya perikanan pesisir. Dalam Prosiding Simposium Nasional Hasil Riset Kelautan dan Perikanan tahun 2007. Badan Riset Kelautan dan Perikanan, Jakarta, hlm. 1-29.

Mustafa, A., Radiarta, I N., \& Rachmansyah. 2011. Profil dan Kesesuaian Lahan Akuakultur Mendukung Minapolitan. Sudradjat, A. (Ed.) Pusat Penelitian dan Pengembangan Perikanan Budidaya, Jakarta, $91 \mathrm{hlm}$.

Mustafa, A., Sapo, I., Hasnawi, \& Sammut, J. 2007b. Hubungan antara faktor kondisi lingkungan dan produktivitas tambak untuk penajaman kriteria 
kelayakan lahan: 1. Kualitas air. J. Ris. Akuakultur, 2(3): 289-302.

Poernomo, A. 1979. Budidaya udang di tambak. Dalam Soegiarto, A., Toro, V., \& Soegiarto, K.A. (Eds.) Udang: Biologi, Potensi, Budidaya, Produksi, dan Udang sebagai Bahan Makanan di Indonesia. Lembaga Oseanologi Nasional-Lembaga IImu Pengetahuan Indonesia, Jakarta, hlm. 77-174.

Poernomo, A. 1988. Pembuatan Tambak Udang di Indonesia. Seri Pengembangan No. 7. Balai Penelitian Perikanan Budidaya Pantai, Maros, $40 \mathrm{hlm}$.

Ponce-Palafox, J., Martinez-Palacios, C.A., \& Ross, L.G. 1997. The effect of salinity and temperature on the growth and survival rates of white shrimp, Penaeus vannamei, Boone, 1931. Aquaculture, 157: 107-115.

Poxton, M. 2003. Water quality. In Lucas, J.S. \& Southgate, P.C. (Eds.) Aquaculture: Farming Aquatic Animals and Plants. Blackwell Publishing Ltd., Oxford, p. 47-73.

Radiarta, I N. , Saputra, A., \& Ardi, I. 2011. Anal isis spasial kelayakan lahan budidaya kerang hijau (Perna viridis) berdasarkan kondisi lingkungan di Kabupaten Cirebon, Jawa Barat. J. Ris. Akuakultur, 6(2): 341-352.

Rossiter, D.G. 1996. A theoretical framework for land evaluation. Geoderma, 72: 165-202.

Saaty, T.L. 1977. A scaling method for priorities in hierarchical structures. Journal of M athematical Psychology, 15: 234-281.
Saaty, T.L. 1993. Pengambilan Keputusan: Proses Hirarki Analitik untuk Pengambilan Keputusan dalam Situasi yang Kompleks. Diterjemahkan: Peniwati, K. PT Pustaka Binaman Pressindo, Jakarta, $270 \mathrm{hlm}$.

Sawyer, C.N. \& McCarty, P.L. 1978. Chemistry for Environmental Engineering. Third edition. McGraw-Hill Book Company, New York, 532 pp.

Schmidt, F.H. \& Ferguson, J.H.A. 1951. Rainfall type based on wet and dry period ratios for Indonesia with Western New Gurinea. Verhandelingen, 42: 77 pp. plus figures.

Soewito, Cholik, F., \& Moeslim, S. 2011. Perikanan Indonesia: Masa Lalu, Kini dan Masa Depan. Masyarakat Perikanan Nusantara, Jakarta, $204 \mathrm{hlm}$.

Stickney, R.R. 2000. Tilapia Culture. In Stickney, R.R. (Ed.) Encyclopedia of Aquaculture. John Wiley \& Sons, Inc., New York, p. 934-941.

Swingle, H.S. 1968. Standardization of chemical analysis for waters and pond muds. FAO Fisheries Report, 44(4): 397-406.

Watanabe, W.O. 2000. Salinity. In Stickney, R.R. (Ed.) Encyclopedia of Aquaculture. John Wiley \& Sons, Inc., New York, p. 767-772.

Wiryanta, B.T.W., Sunaryo, Astuti, \& Kurniawan, M.B. 2010. Budi Daya \& Bisnis Ikan Nila. PT Agromedia Pustaka, Jakarta, $210 \mathrm{hlm}$. 